УСТИНКИН Сергей Васильевич - доктор исторических наук, профессор; директор Приволжского филиала ФНИСЦ РАН (603000, Россия, г. Нижний Новгород, Холодный пер., 4.), начальник научноисследовательской лаборатории изучения мировых и региональных социально-политических процессов, научный руководитель Высшей школы международных отношений и мировой политики Нижегородского государственного лингвистического университета им. Н.А. Добролюбова (603950, Россия, г. Нижний Новгород, ул. Минина, 31A; sv.ustinkin@gmail.com)

ФОМЕНКОВ Артем Александрович - доктор исторических наук, доцент; старший научный сотрудник международной междисииплинарной научно-исследовательской лаборатории изучения мировых и региональных социально-политических процессов Нижегородского государственного лингвистического университета им. Н.А. Добролюбова (603950, Россия, г. Нижний Новгород, ул. Минина, 31A; artjom2310@inbox.ru)

\title{
СОГЛАСИЕ РОССИЙСКОЙ ФЕДЕРАЦИИ И ИСЛАМСКОЙ РЕСПУБЛИКИ ИРАН ПО УРЕГУЛИОВАНИЮ ВООРУЖЕННОГО КОНФЛИКТА В СИРИИ
}

Аннотация. В статье рассматриваются вопросы урегулирования вооруженного конфликта на территории Сирии. Авторы делают ряд выводов относительно совпадения российской и иранской позиций по сирийскому урегулированию и признают, что согласие по данной проблеме объективно содействует углублению межгосударственного сотрудничества между РФ и ИРИ, а союз между странами носит стратегический характер.

Ключевые слова: Сирия, ООН, Иран, Российская Федерация, вооруженный конфликт, урегулирование, международные организации, шииты, успешность, союз, сотрудничество

B ооруженный конфликт на территории Сирийской Арабской Республики со всей очевидностью продемонстрировал не только какие именно государства стремятся к установлению мира в таком взрывоопасном регионе, как Ближний Восток, но также и то, какие страны могут по-настоящему считаться союзниками Российской Федерации.

Нельзя не признать, что роль международных организаций в урегулировании вооруженного противостояния в Сирии крайне низка. Касается это даже $\mathrm{OOH}$, которая, по замыслу своих создателей, и должна была заниматься решением такого рода проблем. К сожалению, следует признать, что государства, руководствующиеся своими национальными интересами, и по сей день эффективнее, нежели руководствующиеся международным правом и абстрактными ценностями международные институты.

В целом, по нашему мнению, в первую очередь наличествует совпадение позиций по сирийской проблеме у Российской Федерации и Исламской Республики Иран. Именно эти государства, наряду с Турецкой Республикой, запустили астанинский процесс, являющийся наиболее действенным по отношению к сирийскому конфликту. Упомянем, что именно «Анкара и Тегеран наряду с Москвой выступили посредниками в организации очередных раундов межсирийских переговоров в январе-феврале 2017 г. в Астане и Женеве» [Иванов 2017: 46]. Данные переговоры в итоге и привели к коренному изменению ситуации в Сирии в пользу Б. Асада и, соответственно, приблизили наступление мира на территории САР. Важно также указать, что, в отличие от официальной Анкары, Москва и Тегеран всецело поддерживают не сирийскую оппозицию, но Дамаск в лице Б. аль-Асада. 
Нельзя не при этом не признать, что официальный Тегеран зачастую руководствуется иными причинами при выработке своей внешней политики на Ближнем Востоке, нежели Российская Федерация.

Итак, кроме давнего военно-политического сотрудничества с Сирией, большую роль в деле поддержки Б. аль-Асада играет и религиозный фактор. Прежде всего, он связан с тем, что алавиты нередко рассматриваются как течение в исламе, близкое к шиизму, т.е. тому направлению ислама, что доминирует в Иране. Впрочем, нельзя не признать, что «принадлежность алавитов к шиитской ветви ислама в историческом плане оспаривается как суннитскими, так и шиитскими теологами» [Куршаков 2012: 31]. Тем не менее все же можно признать, что отношения между шиитами и алавитами более близкие и менее конфликтные, нежели между суннитами и алавитами.

Далее, следует указать, что усиление позиций суннитов на Ближнем Востоке идет вразрез с иранской стратегией, предусматривающей необходимость всемерной поддержки шиизма. Именно поэтому ИГИЛ ${ }^{1}$ и иные организации террористической направленности являются врагами Ирана [Резаи Фарамани, Вализаде Авати 2016: 20]. Кроме того, и суннитские монархии Персидского залива, с разной степени отрицательности относящиеся к официальному Дамаску, также являются оппонентами Тегерана. Как справедливо отмечали исследователи, «противостояние их с Ираном усилилось после начала конфликта в Йемене в 2015 г., а также после казни в Королевстве Саудовской Аравии (КСА) в начале 2016 г. видного шиитского богослова шейха Нимра и 46 представителей шиитского меньшинства» [Долгов 2018: 90-91].

Никак нельзя обойти вниманием и тот факт, что именно через Сирию традиционно идет иранская поддержка «Хезболлы» в Ливане (деятельность означенной шиитской организации отвечает стратегическими интересам ИРИ) [Агасарян 2019: 18; Лукьянов 2013: 75]. Верно также мнение, согласно которому именно «через совместную поддержку "Хезболлы” образовался стратегический союз Сирии и Ирана, или, как его еще называют, ось Дамаск - Тегеран» [Комлева 2016: 5]. Верно также и то, что «в случае падения режима Б. Асада шиитский анклав Леванта, который сейчас держится на усилиях “Хезболлы”, будет отрезан от канала внешней поддержки. Кроме того, поражение Сирии усилит агрессивное давление на шиитское меньшинство в целом ряде арабских монархий» [Комлева 2016: 5].

Нельзя не отметить и антиамериканскую и антиизраильскую направленность действий ИРИ в Сирии. Не случайно, например, «верховный лидер Ирана аятолла А. Хаменеи в этой связи заявил: “В Сирии заметны происки Америки и Израиля. Мы одобряем любое народное исламское движение, противостоящее США”» [Куршаков 2012: 31]. Это вполне логично ввиду санкций, которые введены Соединенными Штатами против Ирана.

Таким образом, «в нынешней кризисной ситуации отношения между Ираном и Сирией по-прежнему характеризуются как стратегическое партнерство. Этому, безусловно, способствует "общность региональных интересов и схожесть позиций по ключевым проблемам Ближнего Востока"» [Скуратова 2015: 115]. Данным обстоятельством объясняется тот факт, что «Иран мобилизовал на помощь Асаду боевиков-шиитов из Ливана, Афганистана, Пакистана, Йемена, Ирака и других стран» [Кошкин 2018: 59-60].

Самое главное, что на текущий момент позиции РФ и ИРИ в наибольшей мере содействуют мирному урегулированию на Ближнем Востоке. Нельзя, конечно, отрицать, «что несмотря на опыт сотрудничества этих стран в сфере

1 Деятельность его запрещена на территории Российской Федерации. 
урегулирования гражданских конфликтов в Таджикистане и в некоторой степени в Афганистане, совместную работу по разрешению сирийского конфликта РФ и ИРИ начали только в 2016 году» [Саламова 2019: 26] (противостояние к этому времени в САР уже длилось не один год!), т.е. российско-иранский союз сложился далеко не сразу. Причины этого заключались в различиях в понимании национальных интересов. Однако самое главное - признание легитимности Б. аль-Асада и стремление сохранить Сирию в ее нынешних границах, равно как и отсутствие ставки на внутрисирийскую оппозицию, делают Россию и Иран полноценными союзниками.

Современное состояние российско-иранских отношений, особенно в свете сирийского урегулирования, дают основания признать всецело соответствующими реальной действительности слова главы российского МИДа С.В. Лаврова, что «наши отношения с ИРИ основываются на принципах дружбы и добрососедства и не подвержены политической конъюнктуре. Политический диалог между нашими лидерами поддерживается на постоянной основе и в последнее время отличается высокой интенсивностью. В 2019 г. президенты России и Ирана встречались четыре раза, в текущем году - трижды общались по телефону» 1 .

Логичным в этих реалиях выглядит и экономическое сближение Ирана и России, особенно с такой структурой, как ЕАЭС, где РФ является лидером. Не случайно С.В. Лавров заявил, что «отдельно хотели бы отметить большое значение, которое придаем реализации вступившего в силу Временного соглашения, ведущего к образованию зоны свободной торговли между ЕАЭС и Ираном. По этому случаю Президент Ирана Х. Рухани принял участие в саммите ЕАЭС на высшем уровне, состоявшемся в Ереване 1 октября 2019 г. Данное соглашение послужит основой для расширения торгово-экономического сотрудничества с Ираном» 2 .

Таким образом, признаем, что между Российской Федерацией и Исламской Республикой Иран имеется согласие по сирийскому вопросу, которое, в свою очередь, содействует укреплению межгосударственного сотрудничества и в других сферах, прежде всего в экономической. То есть, союз этот можно признать носящим стратегический характер.

\section{Список литературы}

Агасарян В.К. 2019. Роль Исламской Республики Иран в Сирийском кризисе. - Регион и мир. Т. 10. № 4. С. 18-20.

Долгов Б. 2018. Сирийский конфликт на новом этапе: международное измерение. - Перспективы: электронный журнал. № 3(15). С. 86-99.

Иванов С. 2017. Вооруженные конфликты в Сирии и Ираке. - Россия и мусульманский мир. № 9(303). С. 41-52.

Комлева Н.А. 2016. Иран: геополитический портрет. - Альманах Пространство и Время: электронное научное издание. Т. 13. № 1.

Кошкин Р.П. 2018. Сирийский кризис: Геополитика и проблемы восстановления страны. - Стратегические приоритеты. № 3(19). С. 58-73.

\footnotetext{
${ }^{1}$ Комментарий Департамента информации и печати МИД России в связи с переговорами Министра иностранных дел России С.В. Лаврова с Министром иностранных дел Ирана М.Д. Зарифом. Доступ: https://www.mid.ru/web/guest/adernoe-nerasprostranenie/-/asset_ publisher/JrcRGi5UdnBO/content/id/4349358 (проверено 10.03.2021).

2 Ответы Министерства иностранных дел Российской Федерации на вопросы СМИ, полученные к пресс-конференции по итогам деятельности российской дипломатии в 2019 году. Доступ: https://www.mid.ru/web/guest/mezdunarodnaa-informacionnaa-bezopasnost/-/ asset_publisher/UsCUTiw2pO53/content/id/3995958 (проверено 10.03.2021).
} 
Куршаков В. 2012. Шиитский фактор во внешней политике Ирана. - Мировая экономика и международные отношения. № 11. С. 24-32.

Лукьянов М.А. 2013. Сирия: Два года политической лабильности. - Вестник Кемеровского государственного университета. № 4-2(56). С. 74-79.

Резаи Фарамани Р., Вализаде Авати К. 2016. Последствия усиления позиций ИГИЛ для Ирана. - Центральная Азия и Кавказ. Т. 19. № 2. С. 19-35.

Саламова М.X. 2019. Внешние политические отношения России и Ирана в контексте урегулирования сирийского конфликта. - Вестник современных исследований. № 5.3(32). С. 25-28.

Скуратова Ю.Ю. 2015. Влияние взаимоотношений Ирана и Саудовской Аравии на кризис в Сирии. - Вестник Московского университета. Сер. 21: Управление (государство и общество). № 4. С. 103-118.

USTINKIN Sergey Vasilyevich, Dr.Sci. (Hist.), Professor; Director of the Volga Branch of the Federal Center of Theoretical and Applied Sociology, Russian Academy of Sciences (4 Holodny Lane, Nizhny Novgorod, Russia, 603000; sv.ustinkin@ gmail.com), Head of the International Cross-Disciplinary Laboratory for Studies of Global and Regional Sociopolitical Processes, Dobroljubov State Linguistics University of Nizhny Novgorod; Scientific Director of the Higher School of International Relations and World Politics, Dobroljubov State Linguistics University of Nizhny Novgorod (31a Minina St, Nizhny Novgorod, Russia, 603950; sv.ustinkin@gmail.com)

FOMENKOV Artyom Aleksandrovich, Dr.Sci. (Hist.), Associate Professor, Senior Researcher of the International Cross-Disciplinary Laboratory for Studies of Global and Regional Sociopolitical Processes, Dobroljubov State Linguistics University of Nizhny Novgorod (31a Minina St, Nizhny Novgorod, Russia, 603950; artjom2310@inbox.ru)

\section{CONSENSUS BETWEEN THE RUSSIAN FEDERATION AND THE ISLAMIC REPUBLIC OF IRAN ABOUT THE SETTLEMENT OF THE ARMED CONFLICT IN SYRIA}

\footnotetext{
Abstract. The article is devoted to the study of the settlement of the Syrian armed conflict. The authors make some conclusions about the coincidence of the Russian and Iranian positions in the Syrian settlement and note that the coordination on this issue objectively contributes to the deepening of interstate cooperation between the Russian Federation and Iran. They conclude that the alliance between the two states is a strategical one.

Keywords: Syria, UN, Iran, Russian Federation, armed conflict, settlement, international organizations, Shiites, success, alliance, cooperation
} 